\title{
The Influence of Human Resource Management Practices on Employees Job Performance in Federal University Libraries in Nigeria
}

\author{
Maimuna Izah \\ National Institute for Legislative and Democratic Studies, Abuja \\ Tel: +2348035889731_E-mail: maimunahu@yahoo.com \\ Zakari Mohammed \\ Dept. of Library and Information Science, Ahmadu Bello University, Zaria
}

\begin{abstract}
The study assessed, from survey, the influence of human resource management practice as it relates to employees' job performance in some Federal university libraries in the six geo-political zones of Nigeria. Stratified random sampling technique was employed to come up with six universities from each of the six zones. The researchers administered 7 copies of questionnaire each in the study areas to elicit data on the employees' job performance. A total of 42 copies of questionnaire were administered and retrieved (100\% response rate). The data collected were analysed descriptively and inferentially. The null hypothesis was tested using Kruskal Wallis statistical method. The descriptive analysis result showed that majority of the libraries studied reported that human resources management practices influenced their employees' job performance. Inferentially, the human resources management practices have significantly influenced their staff performances. The study recommended that Federal University libraries should operate uniform human resources management practices policy enhance staff productivity, effectiveness and efficiency in their work places.
\end{abstract}

Keywords: Human resources, human resource management, human resource management practices, university library, job performance

DOI: $10.7176 / \mathrm{IKM} / 10-4-07$

Publication date: July $31^{\text {st }} 2020$

\section{Introduction}

Every organ of an institution, particularly academic libraries, found in universities are to also concern themselves with those employed in the libraries to perform different tasks because the libraries have been described as "the heartbeat of the University". The libraries' roles include facilitation and provision of support services to ensure that teaching, learning and research basic functions are achieved. This could be through accessing and retrieving needed information resources, utilisation of relevant services and encouragement of interactions, communication and sharing of physical and remote information resources among the stakeholders. This suggests the need for unified work policy guiding the employees to be fully motivated, committed, productive and receptive to meet the goals and objectives of the libraries.

In order to appreciate the thrust of the study, human resources, human resource management and human resource management practice shall be contextualise. Human resource simply refers to the people (personnel/staff) an organization employ to carry out various jobs, tasks and functions in exchange for wages and other rewards (DeNisi et al. cited in Alshaikhly, 2017). According to Mishra (2012), no resource in the world, even in this age of microchips and globalization, is more important than human resource. Essentially, human resources are the individuals who perform distinguishable roles in different work places in organisations including institutions.

Human Resource Management (HRM) is responsible for the attraction, selection, training, and assessment and rewarding of employees. Generally, the HRM to ensure better organisational leadership, culture and compliance with employment and labour laws. As an office, HRM focuses on staff recruitment, management and provision of direction for the people who work in organisations. It categorises them by acknowledging those endowed with a range of abilities, talents and attitudes that influence productivity, quality and profitability to the organisation. It sets overall strategies, goals, design work systems, produce goods and services, monitor quality, allocate financial resources, and market the products and services.

Human Resources Management Practices (HRMP) are the set of techniques, policies, methods, activities, functions and actions designed by organisations, including universities and firms, to ensure that employees contribute meaningfully and effectively to achieve the set goals and objectives. Schuler and Jackson cited in Tan and Nasurdin (2011) defined Human Resource Management Practices as a system that attracts, develops, motivates, and retains employees to ensure effective implementation and survival of an organisation and its members. The management 
practices comprised recruitment, selection, compensation, benefits, training and development, performance appraisal, health, safety, etc. The practices have significant influence on staff job performance because it helps to effectively manage human resources and increase their job performance. As revealed by Munjuri (2011), the way an organisation manages people can influence performance. That if the right people are recruited, trained and motivated, there is the tendency that they would perform well in their jobs.

Like other organisations, University Libraries practice human resource management in areas not limited to recruitment, selection, compensation, benefits, training and development, performance appraisal, health and safety to supply the library with competent and talented employees with knowledge, abilities, and skills pertinent to their roles within the library. Each of the management practices is aimed at contributing to the development of library. For instance, staff retention procedures are designed to motivate the employees by providing them with satisfactory pay, benefits, working conditions, etc. Staff training and development are designed to ensure that employees possess the relevant knowledge and skills necessary to be effective and efficient in performing their duties. Similarly, staff performance appraisal is designed to monitor the job performance of employees by observing variances between the set goals and actual performance so as to take corrective actions when deficiencies are identified. Thus, to be able to effectively manage human resource who would support the University Libraries in contributing meaningfully to the realisation of their universities' goals and objectives, appropriate and adequate human resources management practices (HRMP) is desirous. Basically, the paper is to assist University Libraries achieve their goals and objectives through application of responsive Human Resources Management Practices (HRMP).

\section{Objective of the Study}

It is to determine the extent to which HRMP (recruitment, training and development, retention and performance appraisal) influence employees' job performance in Federal University Libraries in Nigeria.

\section{Hypothesis}

The following null hypothesis was tested:

Ho: The HRMP employed by the Nigerian University Libraries have no significant influence on their staff Job performance

\section{4. $\quad$ Literature Review}

4.1 Human Resources Management Practices (HRMP)

University libraries are expected to attract, train, motivate, and appraise their staff so that they can effectively perform their jobs to provide effective and efficient and services to the University Community. Studies have shown that there is a link between HRMP and employee job performance. According to Dalery and Doty in Shabnam (2013), HRMP can be conceptualised as a set of internally consistent policies and practices designed and implemented to ensure that a firm's human capital contributes to the achievement of its business objectives. Minbaeva cited by Tanand Nasurdin (2011) opined that HRMP is a set of practices used by organizations to manage human resources that facilitate the development of specific competencies that are specific and can produce complex social relationships needed to generate requisite knowledge necessary to sustain competitive advantage. A study by Kaveri and Prabaram (2013) on the impact of Human resources practices on performance of a manufacturing company reported that there is a very strong positive relationship between HR practices and job performance. Hassan cited in Loganathan and Dharmaraj (2017) underscored the impact of HRMP on employees' performance in textile industry in India. They found positive and significant relationship in HRMP (compensation, performance appraisal, trainings, and welfare).

Ghebregiogis and Karsten cited by Okpara and Wynn (2008) averred that the concept and knowledge of HRM Practices such as training, recruitment, compensation, performance appraisal and reward systems are practiced in Eritrea. Anakwe (2002) examined HRM Practices from the traditional HRM functions, such as training and development; recruitment and selection, performance appraisal among others are very much practiced by HR Professionals in Nigeria.

Tayeh (2010) studied Human Resources Management practices (career planning, training, selection and compensation). He found that there is a relationship between these practices and personnel effectiveness. To him, the entire variables have strong positive correlation with personnel's performance. In the banking sector, Soomro (2011) reported 7 HRM practices that are positively correlated with employee performance. They comprised training, selection, career planning, employee participation, job definition, compensation, and performance appraisal. 


\subsection{Employee Job Performance and Human Resources Management Practices}

Studies have shown that there is link between employee job performance and HRMP. Employee are composed of individuals who are organised in certain ways in order to achieve an organisations' objectives so that the job they performance speaks of effectiveness and efficiency (Zaidi, 2011). Khandekar and Sharma cited by Balgobind (2007) defined performance as outcomes that indicate or reflect organization's efficiencies or inefficiencies in terms of cooperate image, compliances and finances.Performance, according to Prasetya and Kato cited by Obicci (2015), is defined as the attained outcome of actions with the skills of employees who perform in some situation. Similarly, Suhartini cited by Khan, et al. (2012), defined employee performance as a mutual result of effort, ability, and perception of tasks.

Rating job performance as good performance relates to achieving the quality, quantity, cooperation, dependability and creativity at least in costs and time (Saleh, 2011).Paauwe and Boseline (2012) stated that job performance as outcomes of HRM can be captured in variety of ways, using indicators such as financial outcomes (e.g. profits, sales, market share); organizational outcome (e.g. output measures such as productivity, quality, and efficiencies); and HR-related outcomes (e.g. attitudinal and behavioural impacts among employees, such as satisfaction, commitment and intention to quit).

Essentially, performance without the prefix "job" is one of the crucial factors in maintaining and increasing effectiveness within an organisation. According to Churchill, Ford and Walker cited by Saleh (2011), performance avails the position to be able to determine contributions of personnel, organizational goals and expectations, environmental conditions, motivation, staff skill levels, aptitudes, and role perception. Hence, the quality of employees is the most important influence on performance because they are believed to be the 'backbone' of an organisation.

Incidentally, personnel need guides which Zaidi (2011) proposed as the right policies when they can respond strategically with the company's goals. Also, they can ensure that the HR practices are actually increasing performance of the employees, supervisors and managers responsible for managing the performance of their employees. This suggests that University Libraries should possess such document that can help them apply the provisions appropriately to increase their staff job performance regardless of their areas of operation and specialization.

\section{Methodology}

The study adopted survey research design and used questionnaire as its data collection instrument. The sampling technique adopted was the stratified random sampling technique to come up with the six Federal Universities selected from each of the geopolitical zone in Nigeria. The random technique gave each member of the population an equal chance of being selected (Denga \& Ali cited in NUC, 2015).Forty-two Heads of Division, in the six Federal University Libraries were purposely selected as respondents and were served the research instrument because of their experience and capability to respond to the questions. Questionnaire, according to Olayiwola (2007), are designed to solicit or collect information about the feelings, attitudes, beliefs, experiences, personal characteristics and other feedback from respondents. The entire instrument administered were retrieved and found analysable (100\% response rate). The selected Federal Universities studied are given in Table 1.

Table 1. Selected Universities and Number of Librarians in the University Libraries

\begin{tabular}{lll}
\hline Zones & Universities & Librarian \\
\hline North Central & Federal University of Agriculture, Makurdi, Benue State & $\mathbf{7}$ \\
North East & University of Maiduguri, Maiduguri, Borno State & 7 \\
North West & Usman DanFodio University, Sokoto, Sokoto State & $\mathbf{7}$ \\
South East & Michael Okpara University of Agriculture, Umudike, Imo State & $\mathbf{7}$ \\
South South & University of Calabar, Calabar, Cross River State & $\mathbf{7}$ \\
South West & University of Ibadan, Ibadan, Oyo State & $\mathbf{7}$ \\
\hline Total & 6 & $\mathbf{4 2}$ \\
\hline
\end{tabular}

Sources: Survey research

\section{Data Analysis}

A list of statements was presented to the libraries' Heads of Divisions to indicate whether the HRMP being employed have influence on their staff job performances. The responses were analysed descriptively using frequency distribution and percentages table. Statistical Package for the Social Sciences (SPSS) was used to analyse the data. The hypothesis was analysed using Kruskal Wallis test. The responses were collapsed by 
combining two appropriate range of variations to get a better picture. Table 2 provides descriptive results and Table 3 provided the inferential result, respectively.

Table 2. Extent at which HRMP Influence Employees' Job Performance

\begin{tabular}{|c|c|c|c|c|c|c|c|c|c|c|c|c|c|c|c|c|c|c|}
\hline \multirow{3}{*}{$\begin{array}{l}\text { Influence of } \\
\text { HRMP }\end{array}$} & \multicolumn{18}{|c|}{ University Libraries Studied } \\
\hline & \multicolumn{2}{|l|}{ UAM } & \multirow{2}{*}{$\mathbf{U}$} & \multicolumn{3}{|l|}{ UDUS } & \multicolumn{3}{|l|}{ MAID } & \multicolumn{3}{|l|}{ CAL } & \multicolumn{3}{|l|}{ M.O } & \multicolumn{2}{|l|}{ U.I } & \multirow[b]{2}{*}{$\mathbf{U}$} \\
\hline & IN & OIN & & IN & OIN & $\mathbf{U}$ & IN & OIN & $\mathbf{U}$ & IN & OIN & $\mathbf{U}$ & IN & OIN & $\mathbf{U}$ & IN & OIN & \\
\hline $\begin{array}{l}\text { Recruitment } \\
\text { of competent } \\
\text { and skilled } \\
\text { employees } \\
\text { has influence } \\
\text { on Job } \\
\text { performance }\end{array}$ & $\begin{array}{l}6 \\
(14.2)\end{array}$ & $\begin{array}{l}1 \\
(2.3)\end{array}$ & $\begin{array}{l}0 \\
(0.0)\end{array}$ & $\begin{array}{l}7 \\
(16.6)\end{array}$ & $\begin{array}{l}0 \\
(0.0)\end{array}$ & $\begin{array}{l}0 \\
(0.0)\end{array}$ & $\begin{array}{l}7 \\
(16.6)\end{array}$ & $\begin{array}{l}0 \\
(0.0)\end{array}$ & $\begin{array}{l}0 \\
(0.0)\end{array}$ & $\begin{array}{l}7 \\
(16.6)\end{array}$ & $\begin{array}{l}0 \\
(0.0)\end{array}$ & $\begin{array}{l}0 \\
(0.0)\end{array}$ & $\begin{array}{l}7 \\
(16.6)\end{array}$ & $\begin{array}{l}0 \\
(0.0)\end{array}$ & $\begin{array}{l}0 \\
(0.0)\end{array}$ & $\begin{array}{l}7 \\
(16.6)\end{array}$ & $\begin{array}{l}0 \\
(0.0)\end{array}$ & $\begin{array}{l}0 \\
(0.0)\end{array}$ \\
\hline $\begin{array}{l}\text { Training on } \\
\text { relevant job } \\
\text { skills has } \\
\text { influence on } \\
\text { Job } \\
\text { performance }\end{array}$ & $\begin{array}{l}7 \\
(16.6)\end{array}$ & $\begin{array}{l}0 \\
(0.0)\end{array}$ & $\begin{array}{l}0 \\
(0.0)\end{array}$ & $\begin{array}{l}7 \\
(16.6)\end{array}$ & $\begin{array}{l}0 \\
(0.0)\end{array}$ & $\begin{array}{l}0 \\
(0.0)\end{array}$ & $\begin{array}{l}7 \\
(16.6)\end{array}$ & $\begin{array}{l}0 \\
(0.0)\end{array}$ & $\begin{array}{l}0 \\
(0.0)\end{array}$ & $\begin{array}{l}7 \\
(16.6)\end{array}$ & $\begin{array}{l}0 \\
(0.0)\end{array}$ & $\begin{array}{l}0 \\
(0.0)\end{array}$ & $\begin{array}{l}7 \\
(16.6)\end{array}$ & $\begin{array}{l}0 \\
(0.0)\end{array}$ & $\begin{array}{l}0 \\
(0.0)\end{array}$ & $\begin{array}{l}7 \\
(16.6)\end{array}$ & $\begin{array}{l}0 \\
(0.0)\end{array}$ & $\begin{array}{l}0 \\
(0.0)\end{array}$ \\
\hline $\begin{array}{l}\text { Retention } \\
\text { Strategies } \\
\text { e.g. Staff } \\
\text { welfare, } \\
\text { benefit, } \\
\text { professional } \\
\text { development, } \\
\text { etc. have } \\
\text { influence on } \\
\text { Job } \\
\text { performance }\end{array}$ & $\begin{array}{l}7 \\
(16.6)\end{array}$ & $\begin{array}{l}0 \\
(0.0)\end{array}$ & $\begin{array}{l}0 \\
(0.0)\end{array}$ & $\begin{array}{l}7 \\
(16.6)\end{array}$ & $\begin{array}{l}0 \\
(0.0)\end{array}$ & $\begin{array}{l}0 \\
(0.0)\end{array}$ & $\begin{array}{l}6 \\
(14.2)\end{array}$ & $\begin{array}{l}0 \\
(0.0)\end{array}$ & $\begin{array}{l}1 \\
(2.3)\end{array}$ & $\begin{array}{l}7 \\
(16.6)\end{array}$ & $\begin{array}{l}0 \\
(0.0)\end{array}$ & $\begin{array}{l}0 \\
(0.0)\end{array}$ & $\begin{array}{l}5 \\
(11.9)\end{array}$ & $\begin{array}{l}1 \\
(2.3)\end{array}$ & $\begin{array}{l}1 \\
(2.3)\end{array}$ & $\begin{array}{l}7 \\
(16.6)\end{array}$ & $\begin{array}{l}0 \\
(0.0)\end{array}$ & $\begin{array}{l}0 \\
(0.0)\end{array}$ \\
\hline $\begin{array}{l}\text { Performance } \\
\text { Appraisal to } \\
\text { monitor and } \\
\text { assess job } \\
\text { performance } \\
\text { has influence } \\
\text { on Job } \\
\text { performance }\end{array}$ & $\begin{array}{l}7 \\
(16.6)\end{array}$ & $\begin{array}{l}0 \\
(0.0)\end{array}$ & $\begin{array}{l}0 \\
(0.0)\end{array}$ & $\begin{array}{l}7 \\
(16.6)\end{array}$ & $\begin{array}{l}0 \\
(0.0)\end{array}$ & $\begin{array}{l}0 \\
(0.0)\end{array}$ & $\begin{array}{l}7 \\
(16.6)\end{array}$ & $\begin{array}{l}0 \\
(0.0)\end{array}$ & $\begin{array}{l}0 \\
(0.0)\end{array}$ & $\begin{array}{l}7 \\
(16.6)\end{array}$ & $\begin{array}{l}0 \\
(0.0)\end{array}$ & $\begin{array}{l}0 \\
(0.0)\end{array}$ & $\begin{array}{l}7 \\
(16.6)\end{array}$ & $\begin{array}{l}0 \\
(0.0)\end{array}$ & $\begin{array}{l}0 \\
(0.0)\end{array}$ & $\begin{array}{l}7 \\
(16.6)\end{array}$ & $\begin{array}{l}0 \\
(0.0)\end{array}$ & $\begin{array}{l}0 \\
(0.0)\end{array}$ \\
\hline
\end{tabular}

KEY: UAM=University of Agriculture Markudi, UDUS=Usman Danfodio University Sokoto, MAID=

University of Maiduguri, CAL=University of Calabar, M.O. = Michael Okpara University, U.I. =University of Ibadan,

$\mathrm{IN}=$ Influenced, representing Influenced and Highly Influence. $\mathrm{O}=$ Occasionally Influenced, representing Occasionally Influenced and Rarely Influenced. While $U=$ Undecided representing only undecided. In each of the column, the figure on top of the one in the bracket represents the frequency of the respondents, while the one in the bracket represents the percentage of the respondents.

Table 2 revealed results of the extent at which HRMP influence employees' job performance. From the University Libraries studied, the librarians believed that human resource management practices influenced employees' job performance represented by $7(16.6 \%)$. The finding reinforced the outcome of the earlier study by Nassazi (2013) which recorded relationship between recruitment and retention strategies, and organisational performance. These which were part of this investigation among librarians on their job performance. Similarly, Tayeh (2010) and Soomro (2011) confirmed that there is strong position relationship between human resource management practices such as training, selection, recruitment and personnel performance. The directional implication of the two studies implied that appropriate application of HRMP could trigger varied implications that university libraries should benefit from when employed to address weaknesses especially in areas of competence, hardworking, pleasant staff, effectiveness and efficiency on the assigned jobs.

\section{Inferential implication}

There was descriptive statistics of the hypothesis tested, given in Table 3.

Ho: The HRMPs employed by the Nigerian University Libraries has no significant

Influence on their staff job performance 
Table 3. Descriptive statistics of Kruskal Wallis on significant influence of HRMP on job performance of library staff in the Federal University Libraries, Nigeria

\begin{tabular}{|c|c|c|c|c|c|}
\hline \multicolumn{6}{|c|}{ Descriptive Statistics } \\
\hline & $\mathrm{N}$ & Mean & Std. Deviation & Minimum & Maximum \\
\hline VAR00001 & 42 & 14.6667 & 1.66260 & 11.00 & 16.00 \\
\hline VAR00002 & 42 & 3.5000 & 1.72853 & 1.00 & 6.00 \\
\hline
\end{tabular}

Key: VAR00001= Dependent Variable, VAR00002= Independent Variable

Table 3 presents the descriptive statistics of the hypothesis tested. The total number of respondents used represented by $\mathrm{N}$ was 42 . The various means and standard deviations on the influence of HRMP on job performance of library staff were presented. Most of the university library staff in the study believed with the four HRMP statements such as: good recruitment strategy ensures availability of competent and skilled personnel who provide quality service; good retention strategies motivate staff to be more effective and efficient in their job; staff training and retraining make them to be more competent and effective on their jobs; and performance appraisal motivate staff to be more hardworking and responsive in their jobs.

However, among the subjects studied, the rankings according to response on the influence of HRMP on library staff job performance is given in Table 4.The HRMPs employed by the Federal University Libraries have significant influence on their staff job performance, thus, it suggests that with bundle or many HRMP, it is could be more effective for libraries to establish standards that can be employed to attain beneficial study and implementable HRMP rather than the individualise practices which is failing them from mutually reinforcing support.

Table 4. Influence of HRMP employed by Federal University Libraries on library staff job performance

\begin{tabular}{lll}
\hline Universities & N & Mean Rank \\
\hline UAM & 7 & 15.00 \\
UDUS & 7 & 10.14 \\
MAID & 7 & 25.50 \\
CAL & 7 & 26.57 \\
M.O. & 7 & 29.57 \\
U.I. & 7 & 22.21 \\
Total & $\mathbf{4 2}$ & \\
\hline
\end{tabular}

Table4 shows that 29.57was the highest mean rank of the study response from Michael Opara university in the south east geopolitical zone while 10.14 was the lowest from Usmanu Danfodio University found in the north west geopolitical zone. These implied that there are different levels of utilisation of human resource management practices among Federal University Libraries in Nigeria.

Table 5. Test statistics implication of the influence of HRMP on Job Performance in Federal University Libraries in Nigeria

\begin{tabular}{ll}
\hline & Result \\
\hline Chi-Square & 15.261 \\
Df & 5 \\
Asymp. Sig. & .009 \\
\hline
\end{tabular}

Table 5 shows that 0.009 was obtained as $P$ value. The degree of freedom was 5 and 15.261 was the calculated Kruskal Wallis represented by Chi-square. The hypothesis test was performed using $\alpha=0.05$. Thus, using the condition for testing the null hypothesis that stated that HRMPs employed by the Nigerian university libraries has no significant influence on staff job performance should be rejected because 0.009 obtained was less than 0.05 . This implied that HRMP has influence on staff job performance. This finding conforms the position of Tayeh (2010) and Soomro (2011) who stated that there is strong positive relationship in practices such as training and selection and recruitment and personnel performance. This calls for Nigerian university libraries to employ some forms of unified HRMP policy whose strategies could assist to supply competent and motivated staff that can provide quality service in the course of their respective jobs in libraries.

\section{Conclusion and recommendation}

University libraries are expected to attract competent staff and train them in order for them to perform their jobs effectively and efficiently. The libraries are encouraged to motivate their staff in order to retain them. Indeed, the 
extent to which staff perform their jobs is largely dependent on their skills, competences and motivation, which form the crux of HRMP. Hence, it is important for library management to adhere to the requirements of HRMP to hire competent staff, train, motivate them, and appraise the existing ones periodically to determine weaknesses and correct them.

It can be concluded that the university library staff in the study areas believed that HRMP strategies such as good recruitment, good retention, training and personnel appraisal have influence on job performance and therefore a necessity for consideration. Thus, the Nigerian university libraries are recommended to put in place uniform HRMP policies that could encourage employing appropriate strategies for staff recruitment, training and retaining, retention and periodic personnel appraisal to boost their job performance.

\section{Reference}

Alshaikhly, N.A. (2017). The Impact of Human Resource Management Practices on Employees' satisfaction: A field Study in the Jordanian Telecommunication Companies. A Thesis Submitted in Partial Fulfilment for the Requirement for Masters Degree in Business Administration, Faculty of Business, Middle Eastern University, Arman, Jordan

Anakwe, P. (2002). Human Resource Management Practices in Nigeria: Challenges and Insights. International Journal of Human Resource Management, 13 (7) .November.

Balgobind, P. (2007). The Relationship Between Human Relation Management Practices and Organisational Performance in the Manufacturing Sector of the Beer Factory in South Africa. A Research Project Submitted to the Gordon Institute of Business Science, University of Pretoria in Partial Fulfilment of the Requirement for the Degree of Masters of Business Administration Retrieved from repository.up.ac.za $(7 / 8 / 2019)$

Kaveri, M., \& Prabakaran, G. (2013). Impact of High Performance Human Resource Practices on Employees' Job Performance in Leather Goods Manufacturing Companies at Vellore District Bonfring. International Journal of Industrial Engineering and Management Science, 3(1), March www.academia.edu (7/8/2019)

Khan, M. M. et al. (2012). The Impact of Employee Commitment on Employee Satisfaction Rore of Employee Performance as a Moderating Variable. Singapore Journal of Business Economics and Management Studies, 1(2). singerporeanjben.com (6/2/2020)

Loganathan, C., \& Dharmaraj, A. (2017). A Study of Effect of Human Resource Practices on Performance of Textile Processing Units in Tamil Nadu. Journal of Research in Dynamical and Control System. Special Issue in Managerial Studies. July. www.academia.edu (6/2/2020)

Mishra, V. K. (2012). Comparative Study of Essential Qualifications/Experience for Library Staff, Skills Required in ICT Environment and Syllabus of LIS Education in Digital Era: A case study. Retrieved at www.crl.edu.ac.in

Munjiri, M. G. (2011). The Effect of HR Management Practices in Enhancing Employee Performance in Catholic Institution of Higher Learning in Kenya. International Journal of Business Administration. 2(4), www.sciedu.ca

Nassazi, A. (2013). Effects of Training on Employee Performance: Evidence from Uganda. International Journal of Scientific Research and Paper. 3, www.ijsrp.org/reseach-paper (7/8/2019)

National Universities Commission (2015). Monday Bulletin: A Publication of the Office of the Executive Secretary. 10(11), March.

Obicci, A.A. (2015). Effects of Ethical Leadership on Employee Performance in Uganda. Net Journal of Business Management. 3(1), 1-12, January. netjournals.org (3/5/2020)

Okpara, J.O. \& Wynn, P. (2008). Human Resource Management Practices in Transition Economy: Challenges \& Prospects. Management Review News. 31(1), 57 - 76. www.emarketing.net.com (8/7/2019)

Paauwe, J. \& Boseline, P. (2012). HRM and Performance: What's next? Working paper 05 -9.www.ilw.cornell.edu

Saleh, F. (2011). The Influence of Skill Levels on Job Performance of Public Service Employees in Malaysia. Business Management Review, 1 (1), 33 - 40, March.

Shabnam, M. S. (2013). Models of Human Resources Management (HRM) Unit 10 SHRM, Session 2, http://www.ocl.ac (8/3/ 2020)

Soomro, R.B. (2011). Examining the Impact of Human Resources Management (HRM) Practices on Employees' Performance: A case study of Pakistani Commercial Banking Sector. 3(1), $865-877$.

Tan, C.L. \& Nasurdin, M.A. (2011). Human Resources Management Practices and Organizational Turnover: Assessing the Mediating Role of Knowledge Management Effectiveness. Electronic Journal of Knowledge Management (EJKM). 9 (2) article 289 [1]. 
Tayeh, N.S.A. (2010). Human Resources Management Practices and Their Impacts On Personnel's Performance in Jordanian Public Academic Libraries. European Journal of Scientific Research, 47(1), 118-121

Tiwari, P. (2012). Human Resource Management Practices: A Comprehensive Review. Pakistan Business Review, January, 669-705 www.iobm.edu.pk (17/9/2019)

Zaidi, S. (2011)..Impact of HR Practices on Employee Performance. http://www.articles.eezi.com (21/4/ 2019) 